\title{
EFEKTIVITAS FRAKSI AKTIF EKSTRAK ETANOL LABU SIAM (Sechium edule (Jack) Sw) SEBAGAI ANTIHIPERTENSI PADA TIKUS HIPERTENSI YANG DIINDUKSI MONOSODIUM GLUTAMAT
}

\author{
Yance Anas*1), Ika Nilam Cahyani'), Ulum Firnanda Sukma ${ }^{2)}$ \\ ${ }^{1}$ Bagian Farmakologi dan Farmasi Klinik Fakultas Farmasi Universitas Wahid Hasyim \\ ${ }^{2}$ Program Studi S1 Farmasi Fakultas Farmasi Universitas Wahid Hasyim \\ *E-mail: yance.apt@gmail.com
}

\section{INTISARI}

Ekstrak etanol labu siam (Sechium edule (Jack) Sw) telah terbukti mempunyai efek antihipertensi. Dalam rangka penemuan dan identifikasi senyawa aktif, dilakukan fraksinasi terhadap ekstrak tersebut dan diuji aktivitas antihipertensinya. Penelitian ini bertujuan untuk mengetahui efektivitas antihipertensi fraksi n-heksan (FH-EELS) dan etil asetat ekstrak etanol labu siam (FEA-EELS) pada tikus hipertensi yang diinduksi monosodium glutamat (MSG). Proses ekstraksi labu siam menggunakan etanol 70\% dengan metode maserasi. FH-EELS dan FEA-EELS diperoleh melalui fraksinasi bertingkat menggunakan n-heksan dan etil asetat. Efektivitas fraksi uji sebagai antihipertensi diukur pada tikus jantan galur Wistar yang mengalami hipertensi karena perlakuan MSG $100 \mathrm{mg} / \mathrm{kgBB} / \mathrm{hari}$ (p.o) selama 14 hari. Hasil penelitian menunjukkan bahwa FH-EELS dan FEA-EELS terbukti memiliki efek antihipertensi pada tikus hipertensi yang diinduksi MSG. Efek antihipertensi FEA-EELS lebih kuat daripada FH-EELS. Kandungan senyawa aktif dalam FEAEELS perlu diisolasi, diidentifikasi, dikembangkan dan ditetapkan potensinya sebagai kandidat agen antihipertensi.

Kata kunci: Antihipertensi, fraksi etil asetat, labu siam, monosodium glutamat, Sechium edule

\begin{abstract}
Previous studies accomplished that the chayote ethanol extract (Sechium edule (Jack) Sw) had an antihypertensive effect. To get and identify the active compound, we fractionated the extract and evaluated its antihypertensive activity. This study aims to investigate the antihypertensive effect of the n-hexane fraction (HF-CEE) and ethyl acetate fraction of chayote ethanol extract (EAF-CEE) in monosodium glutamate (MSG)-induced hypertensive rats. We made the chayote extract using the maceration method by soaking the chayote simplicia in ethanol 70\%. HF-CEE and EAF-CEE were obtained by stratified fractionation using $n$-hexane and ethyl acetate. An antihypertensive effect of the fraction measured on MSG-induced hypertension male Wistar rats after $M S G 100 \mathrm{mg} / \mathrm{kg}$ BW/day (p.o) treatment for 14 days. The study concluded that HF-CEE and EAF-CEE had an antihypertensive effect in MSG-induced hypertensive rats. The EAF-CEE antihypertensive effect is higher than HF-CEE. Therefore, the FEAF-CEE active compounds need to be isolated, identified, developed, and their potential as an antihypertensive candidate.
\end{abstract}

Keywords: Antihypertensive, chayote, ethyl-acetate fraction, Sechium edule, monosodium glutamate

*Corresponding author:

Journal homepage:http:/www.unwahas.ac.id/publikasiilmiah/index.php/ilmufarmasidanfarmasiklinik 
apt. Yance Anas, M.Sc.

Bagian Farmakologi \& Farmasi Klinik Fakultas Farmasi Universitas Wahid Hasyim

Jl. Menoreh Tengah X/22 Sampangan Semarang 50536

yance.apt@gmail.com

\section{PENDAHULUAN}

Sebagian pasien hipertensi di berbagai negara menggunakan tanaman obat tradisional untuk mengendalikan tekanan darah mereka. Beberapa pasien bahkan hanya menggunakan obat tradisional saja dan sebagian lainnya menggunakan terapi kombinasi obat tradisional dan antihipertensi yang diresepkan dokter. Buah labu siam (Sechium edule (Jack) Sw) merupakan tanaman obat paling banyak digunakan $(34,8 \%)$ oleh pasien hipertensi di Kota Parnambuco (Brazil) sebagai terapi penunjang untuk membantu menurunkan tekanan darah (Nunes dkk., 2015). Di Indonesia, buah labu siam sendiri umumnya dimanfaatkan sebagai salah satu sayuran yang sering dikonsumsi masyarakat. Selain sebagai sayuran, buah labu siam sebenarnya juga telah digunakan di berbagai negara sebagai tanaman obat untuk membantu terapi diabetes mellitus, obesitas, aterosklerosis, hipertensi dan berbagai macam penyakit lainnya (Díaz-de-Cerio dkk., 2019).

Labu siam adalah salah satu tanaman obat yang telah banyak diteliti khasiatnya sebagai antihipertensi. Ekstrak kulit buah labu siam terbukti memiliki efek diuretik (Gaol, 2014) yang akan berpengaruh pada penurunan tekanan darah. Trejo-Moreno dkk. (2018) melaporkan bahwa ekstrak dan fraksi aseton akar labu siam juga terbukti memiliki efek sebagai antihipertensi. Sementara itu, ekstrak etanol buah labu siam mampu menurunkan tekanan darah sistolik dan diastolik tikus hipertensi yang diinduksi MSG (Pratiwi, 2018). Berbagai penelitian lainnya juga telah melaporkan efektivitas labu siam pada pasien hipertensi (Apriyani dkk., 2020; Fauziah dkk., 2019; Fauziningtyas dkk., 2020; Yanti, 2017). Akan tetapi, sejauh ini belum ada penelitian yang melaporkan senyawa aktif dalam buah labu siam yang bertanggung jawab terhadap efek antihipertensi tersebut. Marliana dkk. (2005) melaporkan bahwa senyawa aktif yang terkandung dalam ekstrak etanol labu siam adalah senyawa golongan alkaloid, saponin, kardenolin atau bufadienol dan flavonoid. Beberapa senyawa aktif tersebut diduga berkontribusi terhadap efek antihipertensi buah labu siam. Penelitian ini melaporkan hasil uji efek antihipertensi dari dua fraksi aktif ekstrak etanol labu siam dengan menggunakan model hewan percobaan yang digunakan oleh Pratiwi (2018). Hasil penelitian ini dapat digunakan sebagai data awal dalam rangka penemuan senyawa aktif yang potensial dikembangkan sebagai antihipertensi baru dari labu siam.

\section{METODE PENELITIAN \\ Bahan dan Alat}

Bahan uji yang digunakan dalam penelitian ini adalah labu siam yang diperoleh dari daerah Sumowono, Kabupaten Semarang. Proses identifikasi buah labu siam dilakukan di Laboratorium Ekologi dan Biosistematik Jurusan Biologi, Fakultas Matematika dan Ilmu Pengetahuan Alam, Universitas Diponegoro. Berbagai bahan yang digunakan antara lain, monosodium glumatat (PT. Ajinomoto), etanol 70\%, CMC-Na dan etil asetat yang dibeli dari PT. Brataco Chemika Tbk. dan furosemid (PT. Shamparindo Semarang). Peralatan yang digunakan dalam penelitian ini meliputi oven (Memmert), moisture balance (Ohaus), rotary evaporator (Heidolp), blood pressure analyzer merk CODA (Kent Scientific).

\section{Model Hewan Percobaan}

Tikus hipertensi yang digunakan adalah tikus jantan galur Wistar (usia 2 bulan, berat badan 180-250 g) yang diperoleh dan dipelihara dari Laboratorium Farmakologi Fakultas Farmasi Universitas Wahid Hasyim. Tiga puluh ekor tikus tersebut diadaptasikan terlebih dahulu dalam 
suasana laboratorium selama 7 hari. Dalam masa adaptasi tersebut, tikus dimasukkan ke dalam holder setiap hari supaya tikus terbiasa dan tidak mengalami stress pada saat dilakukan pengukuran tekanan darah. Induksi hipertensi pada tikus dilakukan dengan pemberian monosodium glutamat (MSG) $100 \mathrm{mg} / \mathrm{kg} \mathrm{BB}$ secara per oral, satu kali sehari selama 14 hari. Pengukuran tekanan darah sistolik dan diastolik dilakukan 2 jam setelah pemberian MSG dosis terakhir. Tikus dinyatakan mengalami hipertensi apabila tekanan darah sistoliknya $\geq 140 \mathrm{mmHg}$ (Anas dan Hatimah, 2018).

\section{Pembuatan Fraksi Ekstrak Etanol Labu Siam}

Labu siam seberat $15 \mathrm{~kg}$ disimpan di tempat kering, kemudian dicuci bersih dengan air mengalir dan dipotong-potong dengan ketebalan 6-7 $\mathrm{mm}$ tanpa membuang kulitnya. Potongan tersebut selanjutnya dikeringkan dalam oven dengan pengaturan suhu $55^{\circ} \mathrm{C}(\mathrm{Gaol}, 2014)$. Setelah kering, kadar air simplisia diukur dengan moisture balance. Ukuran simplisia diperkecil dengan alat blender dan diayak dengan ayakan ukuran 40 mesh. Pembuatan ekstrak etanol labu siam menggunakan metode maserasi dilakukan dengan cara merendam $700 \mathrm{mg}$ serbuk simplisia kering buah labu siam dalam $5.250 \mathrm{~mL}$ etanol 70\% (Pratiwi, 2018) selama 3 hari. Rendaman simplisia tersebut disimpan pada tempat yang terhindar dari cahaya matahari sambil sesekali diaduk dan diserkai sehingga diperoleh maserat I. Ampas ditambah etanol 70\% sebanyak $1.750 \mathrm{~mL}$, ditutup dan dibiarkan selama 2 hari, diserkai kembali dan diperoleh maserat II. Maserat I dan II kemudian dicampur dienapkan selama satu malam. Ekstrak kemudian dipekatkan dengan vacum rotary evaporator dengan pengaturan suhu $60^{\circ} \mathrm{C}$. Ekstrak dikumpulkan dan dilakukan perhitungan rendemen.

Fraksinasi dilakukan dengan menggunakan metode ekstraksi cair-cair. Ekstrak etanol labu siam yang digunakan dalam proses fraksinasi adalah seberat $160 \mathrm{~g}$ sehingga membutuhkan 8 kali replikasi. Masing-masing sebanyak 20 gram ekstrak etanol labu siam dilarutkan dalam $200 \mathrm{ml}$ air, dimasukkan ke dalam corong pisah, ditambah pelarut n-heksan sebanyak $200 \mathrm{ml}(1: 1 \mathrm{v} / \mathrm{v})$, digojok perlahan hingga larutan tercampur, kemudian didiamkan sampai kedua fase memisah. Fase nheksan ditampung dalam baker glass hingga tersisa fase air. Proses fraksinasi dengan n-heksan dihentikan apabila fase n-heksan telah jernih. Fraksinasi dilanjutkan dengan menambahkan $200 \mathrm{ml}$ etil asetat ke dalam fase air, digojok perlahan dan didiamkan sampai membentuk dua lapisan (lapisan atas fase etil asetat dan lapisan bawah fase air). Fase etil asetat ditampung dalam baker glass. Fraksinasi dihentikan apabila fase etil asetat sudah jernih. Fraksi n-heksan dan etil asetat yang diperoleh dipekatkan menggunakan penguap vacum rotary evaporator pada suhu $60^{\circ} \mathrm{C}$ sehingga diperoleh FH-EELS dan FEA-EELS.

\section{Uji Aktifitas FH-EELS dan FEA-EELS pada Tikus Hipertensi yang diinduksi MSG}

Tiga puluh ekor tikus hipertensi dengan tekanan darah sistolik $\geq 140 \mathrm{mmHg}$ dibagi ke dalam enam kelompok perlakuan (tiap kelompok terdiri dari 5 ekor). Tikus kelompok I (kontrol hipertensi) mendapat perlakuan CMC-Na 0,5\% 12,5 mL/kgBB/hari. Tikus Kelompok II mendapat perlakuan furosemid $5,04 \mathrm{mg} / \mathrm{kgBB} /$ hari. Tikus kelompok III, IV mendapat perlakuan FH-EELS (66 dan 132) $\mathrm{mg} / \mathrm{kgBB} /$ hari. Semantara itu, tikus kelompok V dan IV mendapat perlakuan FEAEELS (66 dan 132) $\mathrm{mg} / \mathrm{kgBB} / \mathrm{hari}$. Sediaan uji diberikan satu kali sehari selama 14 hari secara per oral (Anas and Hatimah, 2018). Tekanan darah sistolik dan diastolik sebelum dan setelah perlakuan sediaan uji diukur dengan metode non-invansif menggunakan alat CODA (Kent Saintific) berdasarkan prinsip volume pressure recording. Sediaan uji dinyatakan memiliki efek antihipertensi jika terjadi penurunan tekanan darah sistolik dan diastolik yang signifikan pada hari ke-14 perlakuan sediaan uji.

\section{Analisis Data}

Normalitas data tekanan darah sistolik dan diastolik diuji dengan metode Shapiro-Wilk dan Kolmogorov-Smirnov. Perbedaan tekanan darah sistolik dan diastolik, sebelum dan setelah perlakuan sediaan uji dianalisis dengan menggunakan uji T-berpasangan. Sementara itu, perbedaan 
data penurunan tekanan darah antar kelompok perlakuan diuji dengan Anova satu jalan dan Uji Tukey pada taraf kepercayaan $95 \%(\alpha: 0,05)$.

\section{HASIL DAN PEMBAHASAN}

Proses fraksinasi ekstrak etanol labu siam menghasilkan FH-EELS seberat 15,0 g (rendemen: 9,37\%), lebih banyak daripada FEA-EELS (berat: 3,8 g; rendemen: 2,37\%). Hasil penelitian menunjukkan bahwa perlakuan FH-EELS (66 dan 132) $\mathrm{mg} / \mathrm{kg}$ BB dan FEA-EELS (66 dan 132) $\mathrm{mg} / \mathrm{kg}$ BB selama 14 hari mampu menurunkan tekanan darah sistolik (Gambar 1) dan diastolik (Gambar 2) tikus hipertensi yang diinduksi MSG ( $p<0,05)$. FEA-EELS memiliki efek antihipertensi yang lebih baik daripada FH-EELS. FEA-EELS $132 \mathrm{mg} / \mathrm{kg}$ BB mampu menurunkan tekanan darah sistolik tikus hipertensi sebesar16,62 $\pm 0,36 \mathrm{mmHg}$, lebih tinggi dibandingkan FHEELS yang hanya mampu menurunkan tekanan darah sistolik sebesar 4,91 $\pm 0,66 \mathrm{mmHg}(\mathrm{p}<0,05)$. Sementara itu, kedua fraksi tersebut memiliki kemampuan yang relatif sama dalam menurunkan tekanan darah diastolik tikus hipertensi yang diinduksi MSG (p>0,05) (Gambar 3) dengan rara-rata penurunan tekanan darah sekitar $12 \mathrm{mmHg}$. Walaupun demikian, kemampuan FH-EELS dan FEAEELS sebagai antihipertensi pada tikus hipertensi yang diinduksi MSG lebih lemah daripada furosemid $(\mathrm{p}<0,05)$. Furosemid 5,04 mg/kg BB mampu menurunkan tekanan darah sistolik sebesar $39,96 \pm 3,08 \mathrm{mmHg}$ dan diastolik sebesar $31,14 \pm 6,66 \mathrm{mmHg}$ pada tikus hipertensi yang diinduksi MSG.

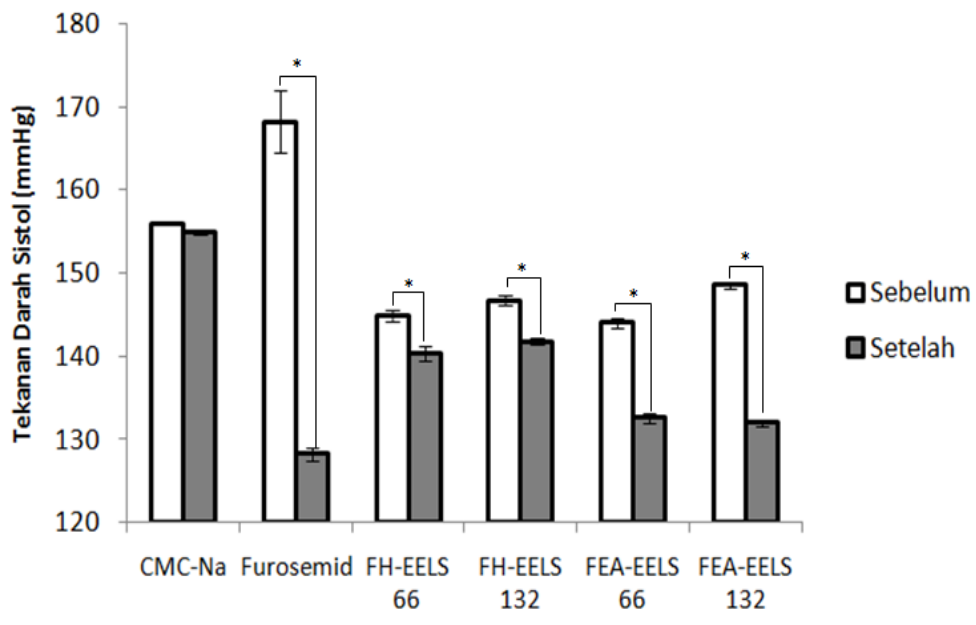

Gambar 1. Tekanan darah sistolik tikus hipertensi sebelum dan setelah perlakuan CMC-Na, furosemid, FH-EELS dan FEA-EELS selama 14 hari. Data disajikan dalam bentuk ratarata \pm SEM ( $\mathrm{n}=5$; n: jumlah tikus hipertensi dalam tiap kelompok). *: berbeda bermakna dengan sebelum perlakuan sediaan uji $(\mathrm{p}<0,05)$ 


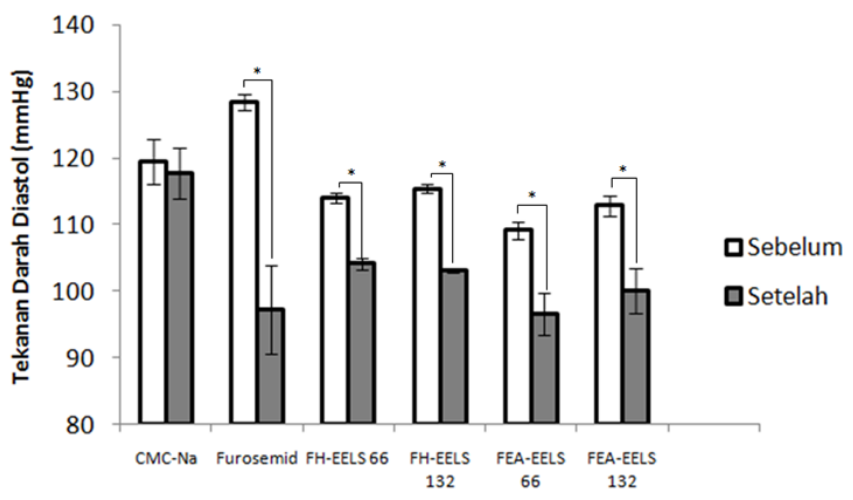

Gambar 2. Tekanan darah diastolik tikus hipertensi sebelum dan setelah perlakuan CMC-Na, furosemid, FH-EELS dan FEA-EELS selama 14 hari. Data disajikan dalam bentuk ratarata \pm SEM ( $=5$; n: jumlah tikus hipertensi dalam tiap kelompok). *: berbeda bermakna dengan sebelum perlakuan sediaan uji $(\mathrm{p}<0,05)$

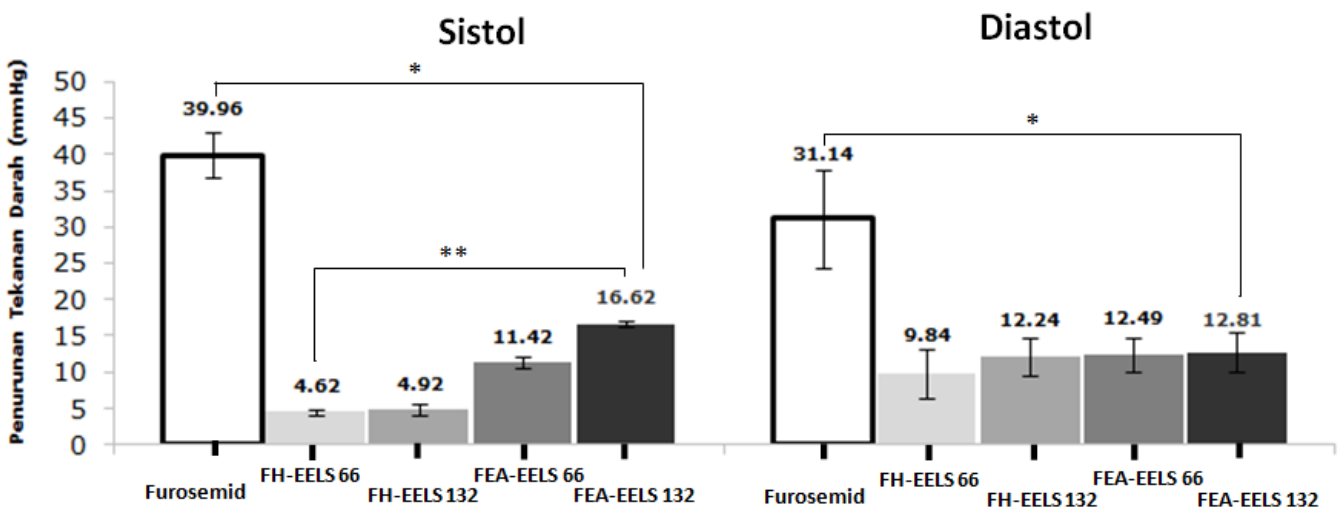

Gambar 3. Penurunan tekanan darah tikus hipertensi setelah perlakuan furosemid, FH-EELS dan FEA-EELS selama 14 hari. Data disajikan dalam bentuk rata-rata $\pm S E M(n=5$; $n$ : jumlah tikus hipertensi dalam tiap kelompok). *: berbeda bermakna dengan furosemid $(\mathrm{p}<0,05)$. **: berbeda bermakna dengan FEA-EELS $132(\mathrm{p}<0,05)$

Hasil penelitian menunjukkan bahwa FH-EELS dan FEA-EELS mampu menurunkan tekanan darah tikus hipertensi yang diinduksi MSG. Perlakuan FH-EELS dan FEA-EELS dosis 132 $\mathrm{mg} / \mathrm{kg}$ BB selama 14 hari mampu menurunkan tekanan darah sistolik dan diastolik tikus hipertensi yang diinduksi MSG berturut-turut sebesar 4,92/12,24 $\mathrm{mmHg}$ dan 16,62/12,81 $\mathrm{mmHg}$. Kemampuan FEA-EELS $132 \mathrm{mg} / \mathrm{kg}$ BB dalam menurunkan tekanan darah yang diinduksi MSG tersebut lebih lemah daripada ekstrak etanol labu siam $132 \mathrm{mg} / \mathrm{kg}$ BB yang mampu menurunkan tekanan darah sistolik dan diastolik tikus hipertensi sebesar 47,32/46,90 mmHg (Pratiwi, 2018). Walaupun demikian, FEA-EELS dapat dikatakan masih memiliki potensi penurun tekanan darah yang baik. Suatu kandidat antihipertensi dapat dikatakan memiliki efek yang poten apabila mampu menurunkan tekanan darah sistolik setidaknya antara $10-12 \mathrm{mmHg}$ dan 5-6 $\mathrm{mmHg}$ untuk tekanan darah diastolik (Lindholm, 2002). Hasil penelitian ini setidaknya dapat memperkaya temuan penelitian sebelumnya mengenai efek antihipertensi buah labu siam. Gordon dkk. (2000) menyatakan bahwa uji pendahuluan yang dilakukan menyimpulkan bahwa ekstrak larut air buah labu siam mampu menurunkan tekanan darah rata-rata tikus teranestesi sebesar $23 \mathrm{mmHg}$. Beberapa penelitian juga telah melaporkan efek labu siam terhadap tekanan darah manusia. Sudibyo (2010) melaporkan jus buah labu siam dapat menurunkan secara signifikan tekanan darah sistolik sebesar 9,05\% dan 10,96\% untuk tekanan darah diastolik pada laki-laki dewasa sehat. 
Sementara itu, Yanti (2017) dalam penelitiannya menyimpulkan bahwa labu siam dapat digunakan sebagai terapi penunjang hipertensi, karena perasan buah labu siam mampu menurunkan tekanan darah sistolik dan diastolik pasien hipertensi sebesar $15 / 9 \mathrm{mmHg}$. Jus buah labu siam juga mampu menurunkan tekanan darah sistolik pasien hipertensi usia lanjut sekitar $3 \mathrm{mmHg}$ (Fauziningtyas dkk., 2020). Penelitian lain yang dilakukan oleh Fauziah dkk. (2019) menyimpulkan bahwa pemberian kapsul ekstrak buah labu siam $500 \mathrm{mg}$ selama 11 hari mampu memperkuat efek penurunan tekanan darah dari antihipertensi yang dikonsumsi oleh ibu hamil yang mengalami hipertensi.

Hasil penelitian ini dapat digunakan sebagai data awal dalam rangka penemuan senyawa aktif yang potensial dikembangkan sebagai kandidat antihpertensi baru dari labu siam. Penelitian selanjutnya dapat diarahkan pada isolasi dan elusidasi struktur senyawa aktif yang terdapat dalam FEA-EELS. Berdasarkan kandungan senyawa aktif dalam ekstrak etanol labu siam yang dilaporkan oleh Marliana dkk. (2005), senyawa aktif yang diduga berada dalam FEA-EELS dan memiliki potensi antihipertensi adalah senyawa golongan flavonoid. Keberadaan senyawa ini perlu dibuktikan dengan cara mengiisolasi senyawa tersebut dan selanjutnya dilakukan elusidasi struktur kimianya, serta diuji efektivitasnya sebagai antihipertensi. Berbagai laporan penelitian telah banyak mengulas tentang efek antihipertensi senyawa flavonoid. Beberapa diantaranya adalah enam senyawa flavonoid yang diisolasi dari Ailanthus excelsa (Roxb) yaitu, kaempferol-3-O- $\alpha$-arabinopiranosida, kaempferol-3-O- $\beta$-galactopiranosida, apigenin, luteolin, kuersetin-3-O- $\alpha$-arabinopiranosida dan luteolin-7-O- $\beta$-glukopiranosida mampu menghambat aktivitas angiotensin converting enzyme (ACE) secara in vitro sehingga berpotensi dikembangkan sebagai antihipertensi. Kaempferol-3-O- $\beta$-galactopiranosida merupakan ACE inhibitor yang paling poten dengan $\mathrm{IC}_{50}$ sebesar $260 \mu \mathrm{M}$ (Loizzo dkk., 2007). Senyawa flavonoid yang paling banyak diteliti sebagai antihipertensi adalah kuersetin yang merupakan penurun tekanan darah cukup potensial pada berbagai model tikus hipertensi, seperti pada model spontaneously hypertensive rats (SHR), L-NAME-treated rats, DOCA-salt hypertensive rats, two-kidney one-clip Goldblatt rats, rats with aortic constriction and Dahl salt-sensitive hypertensive rats (Perez-Vizcaino dkk., 2009).

\section{KESIMPULAN}

FH-EELS dan FEA-EELS terbukti memiliki efek antihipertensi pada tikus hipertensi yang diinduksi MSG. Efek antihipertensi FEA-EELS lebih kuat daripada FH-EELS. Oleh karena itu, kandungan senyawa aktif dalam FEA-EELS perlu diisolasi, diidentifikasi, dikembangkan dan ditetapkan potensinya sebagai antihipertensi.

\section{DAFTAR PUSTAKA}

Anas, Y., dan Hatimah, N.A., 2018, Efek antihipertensi ekstrak etanol kombinasi rambut dan biji jagung (Zea mays L.) pada tikus hipertensi yang diinduksi monosodium glutamat, Jurnal Ilmu Farmasi dan Farmasi Klinik, 15(01), 29-36.

Apriyani, D., Djamil, M., Kumorowulan, S., 2020, Effectiveness of Chayote extract on lowering blood pressure of post partum hypertension, STRADA Jurnal Ilmiah Kesehatan, 9(2), 801812.

Díaz-de-Cerio, E., Verardo, V., Fernández-Gutiérrez, A., and Gómez-Caravaca, A.M., 2019, New insight into phenolic composition of chayote (Sechium edule (Jacq.) Sw.), Food Chemistry, 295, 514-519. https://doi.org/10.1016/j.foodchem.2019.05.146

Fauziah, N.A., Hidajati, K., and Soejoenoes, A., 2019, The effect of chayote extract (Sechium edule) on blood pressure in pregnant women with hypertension, Indonesian Journal of Medisine, 4(3), 266-277.

Fauziningtyas, R., Ristanto, A.C.A., and Makhfudli, 2020, Effectiveness of consumption Sechium edule on decreasing blood pressure in elderly with hypertension in coastal area, IOP 
Conference Series: Earth and Environmental Science, https://doi.org/10.1088/1755$1315 / 519 / 1 / 012005$

Gaol, R.I.L., 2014, Uji efektivitas ekstrak etanol kulit buah labu siam (Sechium edule (Jacq.) Swartz) sebagai diuretik pada tikus jantan galur wistar (Rattus novergicus), Pharmacon, $3(2), 67-72$.

Gordon, E.A., Gordon, L.J., and Nelson, M., 2000, The antihypertensive effects of the Jamaican Cho-Cho (Sechium edule), West Indian Medical Journal, 49(1), 27-31.

Lindholm, L., 2002, The problem of uncontrolled hypertension, Journal of Human Hypertension, 16, S3-S8 (2002).

Loizzo, M.R., Said, A., Tundis, R., Rashed, K., Statti, G.A., Hufner, A., and Menichini, F., 2007, Inhibition of angiotensin converting enzyme (ACE) by flavonoids isolated from Ailanthus excelsa (Roxb)(Simaroubaceae), Phytotherapy research: An International Journal Devoted to Pharmacological and Toxicological Evaluation of Natural Product Derivatives, 21(1), 32-36.

Marliana, S.D., Suryanti, V., and Suyono, 2005, The phytochemical screenings and thin layer chromatography analysis of chemical compounds in ethanol extract of labu siam fruit (Sechium edule Jacq. Swartz.), Biofarmasi Journal of Natural Product Biochemistry, 3(1), 26-31.

Nunes, M.G.S., Bernardino, A., and Martins, R.D., 2015, Use of medicinal plants by people with hypertension, Rev Rene, 16(6), 775-781. https://doi.org/10.15253/21756783.2015000600002

Perez-Vizcaino, F., Duarte, J., Jimenez, R., Santos-Buelga, C., and Osuna, A., 2009, Antihypertensive effects of the flavonoid quercetin, Pharmacological Reports, 61(1), 6775.

Pratiwi, B.A.M., 2018, Efek antihipertensi ekstrak etanol labu siam (Sechium edule) Swartz. pada tikus hipertensi yang diinduksi monosodium glutamat, Skripsi, Fakultas Farmasi, Universitas Wahid Hasyim, Semarang.

Sudibyo, A., 2010, Ffek jus buah labu siam (Sechium edule swartz.) terhadap tekanan darah normal laki-laki dewasa, Skripsi, Universitas Kristen Maranatha.

Trejo-Moreno, C., Castro-Martínez, G., Méndez-Martínez, M., Jiménez-Ferrer, J.E., PedrazaChaverri, J., Arrellín, G., Zamilpa, A., Medina-Campos, O.N., Lombardo-Earl, G., BarritaCruz, G.J., Hernández, B., Ramírez, C.C., Santana, M.A., Fragoso, G., and Rosas, G., 2018, Acetone fraction from Sechium edule (Jacq.) S.w. edible roots exhibits antiendothelial dysfunction activity, Journal of Ethnopharmacology, 220, 75-86. https://doi.org/10.1016/j.jep.2018.02.036

Yanti, E., 2017, Pengaruh pemberian perasan labu siam (Sechium edule) terhadap tekanan darah pada penderita hipertensi, Jurnal Kesehatan Medika Saintika, 8(1), 79-86. https://doi.org/10.30633/88122017201779-861 